\title{
Kejadian Karies Gigi Dan Faktor Risiko Karies Gigi Pada Siswa SD
}

\section{Dental Caries Status And Caries Risk Factors In Students Elementary School}

\author{
Fatin Nur Jauhara', Thresya Febrianti ${ }^{2, *}$ \\ 1,2Universitas Muhammadiyah Jakarta, Jalan K.H. Ahmad Dahlan Ciputat, Cireundeu, Ciputat Timur, Kota Tangerang \\ Selatan, Banten 15419, Indonesia \\ Email: thresya.febrianti@umj.ac.id* \\ *Corresponding Author \\ Tanggal Submisi: 16 Desember 2020, Tanggal Penerimaan: 20 Desember 2020
}

\begin{abstract}
Abstrak
Penelitian ini bertujuan untuk mengetahui prevalensi dan faktor risiko kejadian karies gigi pada siswa SD Labschool FIP UMJ. Desain studi yang digunakan yaitu cross-sectional. Sampel sebanyak 107 siswa, diambil dengan teknik simple random sampling. Analisis bivariat menggunakan uji chi-square. Hasil analisis univariat menunjukkan bahwa 55,1\% responden mengalami kejadian karies gigi. Hasil analisis bivariat menunjukkan bahwa faktor risiko yang mempengaruhi kejadian karies gigi pada siswa antara lain pengetahuan, cara menyikat gigi, dan waktu menyikat gigi. Kerjasama antara puskesmas dan pihak sekolah diperlukan dalam memberikan edukasi yang rutin tentang pemeliharaan gigi dan pemeriksaan gigi rutin pada siswa yang dilakukan oleh puskesmas.
\end{abstract}

Kata kunci: karies gigi; siswa sekolah dasar; faktor risiko

\begin{abstract}
This study aims to determine the prevalence and risk factors for the incidence of dental caries in elementary school students at Labschool FIP UMJ. The study design used was crosssectional. The sample is 107 students, taken by simple random sampling technique. A bivariate analysis used by chi-square test. The results of univariate analysis showed that $55.1 \%$ of respondents experienced dental caries. The results of the bivariate analysis showed that the risk factors that influenced the incidence of dental caries in students were knowledge, how to brush their teeth, and when to brush their teeth. Cooperation between the primary health center and the school is needed in providing regular education about dental care and routine dental checks for students.
\end{abstract}

Keywords: dental caries; elementary school students; risk factor

\section{PENDAHULUAN}

Kesehatan gigi dan mulut masih menjadi masalah kesehatan masyarakat dan memiliki dampak besar jika tidak ditanggulangi. Penyakit gigi dan mulut dapat menyerang seluruh kelompok umur karena memiliki karakteristik yang agresif dan akumulatif. Masalah gangguan gigi dan mulut yang paling sering dialami masyarakat yaitu karies gigi (Kemenkes 2016). 
Berdasarkan data dari The Global Burden of Disease Study tahun 2016, sekitar 3,58 milyar jiwa atau hampir dari setengah populasi di dunia pernah mengalami karies gigi (Kemenkes 2016). Di Indonesia, prevalensi karies gigi mencapai 88,8\% dengan kecenderungan pengalaman karies perorang rata-rata (DMF-T=Decay Missing Filling-Teeth) berkisar antara 7,0-7,2 yang artinya rata-rata masyarakat Indonesia memiliki karies gigi sebanyak 7 setiap orangnya sementara WHO telah menetapkan indeks DMF-T yaitu 3 (Kementerian Kesehatan RI 2018).

Riset Kesehatan Dasar (Riskesdas) tahun 2018 menunjukkan DMF-T pada usia 12 tahun sebesar 1,9 mengalami peningkatan jika dibandingkan hasil Riskesdas tahun 2013 yang menyatakan DMF-T sebesar 1,4. Artinya terjadi kenaikan indeks DMF-T sebanyak 0,5 dari tahun 2013 sampai tahun 2018. Hal tersebut tidak sesuai dengan target DMF-T WHO dalam Global Goals for Oral Health 2020, yaitu < 1. Kejadian karies gigi pada kelompok usia 12 tahun di Indonesia juga masih tinggi yaitu sebesar 72\% (Kementerian Kesehatan RI 2018).

Karies gigi sering menimbulkan dampak pada anak. Salah satu dampak yang paling sering dialami siswa ketika mengalami karies gigi adalah terganggunya konsentrasi belajar anak dan mempengaruhi kehadiran anak di sekolah. Hal tersebut menyebabkan penurunan prestasi anak di sekolah. Dampak lain dari karies gigi yaitu berkurangnya nafsu makan sehingga dapat mengganggu pertumbuhan dan perkembangan anak. Hal ini pun akan mempengaruhi status gizi anak dan berimplikasi pada kualitas sumber daya (Wala 2014).

Penelitian yang dilakukan oleh $\mathrm{Hu}$ et al. (2018) di Cina menunjukkan bahwa jenis kelamin perempuan, pengalaman perawatan gigi yang buruk, konsusmsi susu, teh, kopi dengan gula, dan tinggal di wilayah pedesaan dengan perawatan mulut yang kurang merupakan faktor risiko kejadian karies gigi pada anak. Cina merupakan negara terpadat dan berkembang pesat di dunia, akan tetapi perbedaan dalam status ekonomi, budaya, pendidikan dan pola makan sangat berbeda di antara berbagai wilayah di Cina. Akibatnya pervalensi penyakit mulut sangat berbeda dari satu provinsi ke provinsi lainnya.

SD Labschool FIP UMJ sudah memiliki program pemeriksaan gigi yang dilakukan setiap satu tahun sekali dan program sikat gigi bersama setiap tiga bulan sekali, namun berdasarkan studi pendahuluan yang peneliti lakukan dari 10 siswa yang diperiksa giginya oleh perawat gigi dari keperawatan gigi Poltekkes Jakarta I, didapatkan sebanyak 6 siswa masih mengalami karies gigi. Atas dasar tersebut, peneliti tertarik melakukan penelitian di SD Labschool FIP UMJ mengenai faktor-faktor risiko kejadian karies gigi di SD Labschool FIP UMJ.

\section{METODE PENELITIAN}

Jenis penelitian ini adalah penelitian kuantitatif dengan menggunakan desain studi cross-sectional. Tujuan penelitian ini yaitu untuk mengetahui prevalensi kejadian karies gigi dan faktor-faktor risiko kejadian karies gigi pada siswa kelas IV dan V SD Labschool FIP UMJ. Jumlah seluruh populasi sebanyak 125 siswa dan didapatkan sampel sebanyak 107 siswa. Sampel dipilih dengan menggunakan teknik simple random sampling.

Kriteria inklusi pada penelitian ini adalah siswa yang berumur 9-12 tahun (kelas IV dan V), hadir pada saat pengumpulan data dan bersedia mengikuti proses penelitian. Kriteria 
eksklusi adalah siswa yang sedang mengalami sakit batuk, flu dan demam. Pengumpulan data dilakukan dengan wawancara dan observasi menggunakan kuesioner. Data dianalisis secara univariat dan bivariat dengan menggunakan uji chi-square. Penelitian ini sudah memperoleh kelaikan etik dari Komisi Etik Fakutas Kedokteran dan Kesehatan Universitas Muhammadiyah Jakarta dengan nomor 040/PE/FKK-UMJ/VI/2019.

\section{HASIL DAN PEMBAHASAN}

Tabel 1. Distribusi Responden menurut variabel penelitian pada anak kelas IV dan V

\begin{tabular}{lcc}
\multicolumn{3}{c}{ SD Labschool FIP UMJ tahun 2019} \\
\hline Variabel & n & \% \\
\hline Karies Gigi & 59 & 55,1 \\
Ya & 48 & $44 ., 9$ \\
Tidak & & \\
Pengetahuan & 71 & 66,4 \\
Kurang & 36 & 33,6 \\
Baik & & \\
Cara Menyikat Gigi & 77 & 72,0 \\
Salah & 30 & 28,0 \\
Benar & & \\
Waktu Menyikat Gigi & 47 & 43,9 \\
Salah & 60 & 56,1 \\
Benar & & \\
Frekuensi Periksa Gigi & 85 & 79,4 \\
Tidak Rutin & 22 & 20,6 \\
Rutin & & \\
Periode Pemakaian Sikat Gigi & 42 & 39,3 \\
Tidak Ganti 3 Bulan & 65 & 60,7 \\
Ganti 3 Bulan & & \\
Tingkat Konsumsi Makanan Kariogenik & 46 & 43,0 \\
Tinggi & 61 & 57,0 \\
Rendah & &
\end{tabular}

Tabel 1 menunjukkan bahwa lebih dari setengah responden mengalami karies gigi $(55,1 \%)$, sebanyak $66,4 \%$ siswa mempunyai pengetahuan pemeliharaan kesehatan gigi yang kurang, mayoritas responden memiliki cara menyikat gigi yang salah $(72,0 \%)$, dan mayoritas frekuensi periksa gigi tidak rutin $(79,4 \%)$. Periode pemakaian sikat gigi sudah cukup baik yaitu lebih dari setengah responden sudah mengganti sikat gigi setiap 3 bulan sekali dan setengah dari responden tingkat konsumsi makanan kariogenik rendah (57,0\%).

Tabel 2. Distribusi silang kejadian karies gigi pada siswa SD Labschool FIP UMJ tahun 2019

\begin{tabular}{|c|c|c|c|c|c|c|}
\hline \multirow{2}{*}{ Variabel } & \multicolumn{2}{|c|}{ Karies Gigi } & \multicolumn{2}{|c|}{ Tidak } & \multirow{2}{*}{ PR 95\% CI } & \multirow{2}{*}{$p$} \\
\hline & $\mathbf{f}$ & $\%$ & f & $\%$ & & \\
\hline \multicolumn{7}{|l|}{ Pengetahuan } \\
\hline Kurang & 45 & 63,4 & 26 & 71 & 3,93 & \multirow{2}{*}{0,01} \\
\hline Baik & 11 & 30,6 & 25 & 36 & $(1,66-9,27)$ & \\
\hline \multicolumn{7}{|l|}{ Cara menyikat gigi } \\
\hline Salah & 46 & 59,7 & 31 & 40,3 & 2,69 & \multirow{2}{*}{0,02} \\
\hline Benar & 10 & 33,3 & 20 & 66,7 & $(1,225-7,193)$ & \\
\hline \multicolumn{7}{|l|}{ Waktu menyikat gigi } \\
\hline Salah & 30 & 63,8 & 17 & 36,2 & 2,30 & 0,05 \\
\hline
\end{tabular}




\begin{tabular}{llllrrr}
$\quad$ Benar & 26 & 43,3 & 34 & 56,7 & $(1,05-5,05)$ & \\
$\quad \begin{array}{l}\text { Frekuensi periksa gigi } \\
\quad \text { Tidak }\end{array}$ & 48 & 56,5 & 37 & 43,5 & 2,27 & 0,14 \\
$\quad$ Ya & 8 & 36,4 & 14 & 63,6 & $(0,86-5,98)$ & \\
$\begin{array}{l}\text { Periode pemakaian sikat gigi } \\
\quad<3 \text { bulan }\end{array}$ & & & & & & \\
$\quad>3$ bulan & 34 & 52,4 & 20 & 47,6 & 1,00 & 1,00 \\
$\quad$ Konsumsi makanan & & & 31 & 47,7 & $(0,46-2,18)$ & \\
$\quad$ kariogenik & & & & & & \\
$\quad$ Tinggi & 24 & 52,2 & 22 & 47,8 & 1,01 & 1,00 \\
$\quad$ Rendah & 32 & 52,5 & 29 & 47,5 & $(0,47-2,17)$ & \\
\hline Total & 56 & 100,00 & 51 & 100,00 & & \\
\hline
\end{tabular}

Berdasarkan tabel 2 menunjukkan bahwa pengetahuan pemeliharaan kesehatan gigi merupakan faktor risiko kejadian karies gigi dengan $\mathrm{p}=0,01(\mathrm{p}<0,05)$. Pada variabel perilaku pemeliharaan kesehatan gigi, dari empat faktor perilaku pemeliharaan kesehatan gigi, cara menyikat gigi menjadi faktor risiko kejadian karies gigi dengan $\mathrm{p}=0,02(\mathrm{p}<0,05)$.

Pada variabel waktu menyikat gigi diperoleh $\mathrm{p}=0,05$, yang artinya ada hubungan dengan kejadian karies gigi. Frekuensi periksa gigi ke dokter gigi $(p=0,14)$, periode pemakaian sikat gigi $(\mathrm{p}=1,0)$, dan tingkat konsumsi makanan kariogenik $(\mathrm{p}=1,00)$, tidak ditemukan hubungan yang signifikan dengan kejadian karies gigi ( $p>0,05)$.

Hasil penelitian pada siswa menunjukkan kejadian karies gigi sebanyak 55,1\%. Hasil penelitian Lendrawati et al (2019) pada remaja di Indonesia terdapat $61 \%$ mengalami karies gigi. Rata-rata nilai DMFT 1,3 $\pm 1,4$.

Hasil penelitian pada hubungan tingkat pengetahuan pemeliharaan kesehatan gigi dengan kejadian karies gigi menunjukkan $\mathrm{p}=0,01$. Nilai $\mathrm{PR}=3,93$ (95\% $\mathrm{CI}=1,66-9,27)$. Hal ini berarti siswa yang memiliki pengetahuan kurang memiliki risiko 3,93 kali lebih besar untuk mengalami karies gigi dibandingkan dengan siswa yang memiliki pengetahuan baik. Penelitian Hardika (2018) juga menyatakan bahwa terdapat hubungan yang signifikan antara pengetahuan anak dengan kejadian karies gigi $\mathrm{p}=0,036$ dan $\mathrm{OR}=2,20(95 \% \mathrm{CI}=$ $1,10-4,30)$.

Pengetahuan mengenai kesehatan gigi dan mulut memainkan peranan yang besar bagi terbentuknya sebuah tindakan menjaga kesehatan gigi dan mulut. Saat seseorang memiliki pengetahuan akan sebuah informasi, maka besar kemungkinan untuk orang tersebut bertindak sesuai dengan informasi yang mereka ketahui. Pengetahuan mengenai kesehatan gigi dan mulut merupakan langkah awal peningkatan kesehatan sejak dini (Herijulianti E, Indriani Ts 2001). Berbeda dengan hasil penelitian Taadi and Almujadi (2017) yang menunjukkan tidak ada pengaruh tingkat pengetahuan kesehatan gigi dengan jumlah karies pada siswa SD Muhammadiyah Sangonan II Godean Yogyakarta dengan $\mathrm{p}>0,05$.

Perilaku pemeliharaan kesehatan gigi pada penelitian ini meliputi frekuensi periksa gigi ke dokter gigi, periode pemakaian sikat gigi, waktu yang dilakukan untuk menyikat gigi dan cara menyikat gigi seperti pola menyikat gigi, kandungan fluor dalam pasta gigi. Hasil analisis didapatkan bahwa cara menyikat gigi berhubungan dengan 
kejadian karies gigi dengan $\mathrm{p}=0,02$. Artinya, anak yang salah dalam cara menyikat gigi memiliki peluang $73 \%$ untuk terkena karies gigi dibandingkan dengan anak yang benar dalam cara menyikat gigi.

Penelitian Alini (2018) menyatakan bahwa perilaku menyikat gigi berhubungan secara signifikan dnegan kejadian karies gigi pada murid dengan $\mathrm{p}=0,01$ dan nilai $\mathrm{POR}=2,90$. Artinya, perilaku menyikat gigi yang salah memiliki peluang hampir tiga kali lebih tinggi untuk terkena karies gigi dibandingkan dengan perilaku menyikat gigi benar. Salah satu upaya pencegahan karies gigi yang mudah yaitu dengan menyikat gigi dengan teratur dan cara yang benar. Manfaat menyikat gigi dengan benar antara lain dapat membantu mencegah terbentuknya plak, kerusakan gigi, dan bau napas serta penyakit gusi (Sufriani 2018).

Faktor perilaku pemeliharaan kesehatan gigi selanjutnya adalah waktu menyikat gigi. Hasil analisis menunjukkan bahwa waktu menyikat gigi berhubungan dengan kejadian karies gigi $(\mathrm{p}=0,05)$. Nilai $\mathrm{PR}=2,30$ (CI 95\%=1,05-5,05) artinya anak yang melakukan rutinitas menyikat gigi pada waktu yang salah berisiko 2,3 kali lebih besar mengalami karies gigi dibandingkan dengan anak yang benar waktu menyikat giginya. Sejalan dengan penelitian yang dilakukan Badruddin et al (2017) menyatakan ada hubungan antara waktu menyikat gigi dengan kejadian karies gigi dengan $(p=0,00)$.

Hasil penelitian variabel frekuensi memeriksakan gigi menunjukkan hasil $p=0,14$ ( $>>0,05)$ artinya tidak ada hubungan antara memeriksakan gigi ke dokter dengan kejadian karies gigi pada siswa. Salah satu faktor yang menyebabkan anak tidak rutin memeriksakan gigi adalah orang tua yang tidak disiplin mengajak anak memeriksakan giginya ke dokter gigi. Anak usia 9-12 tahun belum mampu datang ke dokter gigi sendiri, sehingga orang tua memainkan peranan yang penting pada variabel ini. Hasil penelitian ini sejalan dengan penelitian yang dilakukan oleh Agustanti et al (2018) yang menunjukan bahwa tidak terdapat hubungan yang signifikan antara periksa ke dokter gigi dengan kejadian karies gigi, dengan nilai $\mathrm{p}=0,47$. Penelitian yang dilakukan di Jepang oleh Kunitomo et al (2016) juga menunjukkan tidak ada hubungan antara pemeriksaan gigi secara berkala dengan kejadian karies gigi $(\mathrm{p}=0,945)$.

Hasil analisis ditemukan bahwa tidak ada hubungan yang signifikan antara periode penggantian sikat gigi dengan kejadian karies gigi dengan $\mathrm{p}=1,00$. Berbeda dengan hasil penelitian Junarti and Santik (2017) yang menyatakan bahwa ada hubungan antara penggantian sikat gigi dengan kejadian karies gigi $(\mathrm{p}=0,01)$ dan nilai prevalence rate $(\mathrm{PR})=1,6$. Periode pemakaian sikat gigi merupakan salah satu variabel yang penting, karena bulu sikat akan kehilangan kemampuan untuk membersihkan plak pada gigi setelah tiga bulan pemakaian (Kemenkes, 2016). Tidak terdapatnya hubungan antara periode 
pemakaian sikat gigi dengan kejadian karies gigi dapat disebabkan karena nilai distribusi dan frekuensi yang hampir sama.

Pada variabel tingkat konsumsi makanan kariogenik hasil analisis bivariat menunjukkan bahwa tingkat konsumsi makanan kariogenik bukan merupakan faktor risiko kejadian karies gigi pada anak kelas IV dan V SD Labschool FIP UMJ ( $p=1,00)$. Tidak terdapatnya hubungan antara konsumsi makanan kariogenik dengan kejadian karies gigi dapat terjadi karena distribusi frekuensi responden pada variabel ini yang hampir sama. Penyebab lainnya adalah terjadi bias recall pada saat dilakukan wawancara karena responden diharuskan mengingat berapa kali responden mengkonsumsi makanan kariogenik dalam seminggu terakhir selama penelitian berlangsung. Hasil penelitian ini sejalan dengan penelitian yang dilakukan oleh Aprinta, Prasetya, and Wirawan (2018), yang menunjukkan bahwa tidak terdapat hubungan yang signifikan antara frekuensi konsumsi makanan kariogenik dengan kejadian karies gigi molar pertama permanen $(\mathrm{p}=0,89)$.

\section{SIMPULAN}

Lebih dari setengah responden mengalami karies gigi $(55,1 \%)$. Mayoritas responden memiliki pengetahuan kurang $(72,0 \%)$. Sebagian besar reponden salah dalam cara menyikat gigi $(72,0 \%)$. Lebih sari setengah responden benar dalam waktu menyikat gigi $(56,1 \%)$. Sebagian besar responden tidak rutin memeriksakan gigi ke dokter gigi $(79,4 \%)$. Sebagian besar responden tidak rutin menggganti sikat gigi $(60,7 \%)$. Lebih dari setengah responden $(57,0 \%)$ memiliki tingkat konsumsi makanan kariogenik rendah.

Terdapat hubungan yang signifikan antara pengetahuan dengan kejadian karies gigi pada siswa dengabn nilai $\mathrm{p}=0,00$. Terdapat hubungan yang signifikan antara cara menyikat gigi dengan kejadian karies gigi dengan nilai $\mathrm{p}=, 02$. Terdapat hubungan antara waktu menyikat gigi dengan kejadian karies gigi dengan nilai $\mathrm{p}=0,05$.

\section{SARAN}

Bagi siswa dapat melakukan pemeliharan kesehatan gigi seperti menyikat gigi dengan pola menyikat yang benar, menyikat gigi dengan waktu yang benar, sikat gigi diganti minimal setiap tiga bulan sekali dan rutin melakukan pemeriksaan gigi ke dokter gigi setiap enam bulan sekali dengan tujuan mencegah terjadinya karies gigi dan penyakit gigi lainnya. Bagi siswa yang memiliki karies gigi disarankan untuk segera mendapatkan perawatan dari dokter gigi sehingga karies gigi tidak menjadi semakin parah. Perlu adanya peningkatan kerjasama antara puskesmas dan pihak sekolah dalam memberikan edukasi kepada seluruh siswa dalam upaya pemeliharaan kesehatan gigi. 


\section{DAFTAR PUSTAKA}

Agustanti et al. (2018). Dental caries in 12-year-old school children living in Jakarta. Journal of International Dental and Medical Research, 11(1), 23842.

Alini. (2018). Faktor yang berhubungan dengan kejadian karies gigi pada murid SDN 005 Kepenuhan wilayah kerja Puskesmas Kepenuhan. Jurnal Basicedu, 2(1), 19-27.

Aprinta et al. (2018). Hubungan frekuensi menyikat gigi dan konsumsi makanan kariogenik dengan kejadian karies gigi molar pertama permanen pada anak sekolah dasar usia 8-12 tahun di Desa Pertima, Karangasem, Bali. Bali Dental Journal, 2(1), 1-8.

Badruddin et al. (2017). The association between sweet food consumption, time of tooth brushing and dental caries experience in 12-to 15-year-old children in Indonesia (Analysis of Indonesian health basic research data, 2013). Journal of International Dental and Medical Research, 10(special issue), 583-89.

Hardika, Bangun Dwi. (2018). Hubungan pengetahuan dan sikap anak kelas V terhadap terjadinya karies gigi di SD Negeri 131 Palembang. JPP (Jurnal Kesehatan Poltekkes Palembang), 13(1), 37-41. doi: 10.36086/jpp.v13i1.84.

Herijulianti E, Indriani Ts, Artini S. (2001). Pendidikan kesehatan gigi. Jakarta: Buku Kedokteran EGC.

Hu et al. (2018). Dental caries status and caries risk factors in students ages 12-14 years in Zhejiang, China. Medical Science Monitor, 24, 3670-78. doi: 10.12659/MSM.907325.

Junarti, Desti, and Yunita Dyah Puspita Santik. (2017). Perilaku pemeliharaan kesehatan gigi dan status karies. HIGEIA: Journal Of Public Health Research and Development, 1(1), 86.

Kemenkes. (2016). Peraturan Menteri Kesehatan Republik Indonesia No. 89 tahun 2015 tentang upaya kesehatan gigi dan mulut. Indonesia: Berita Negara Republik Indonesia.

Kementerian Kesehatan RI. (2018). Laporan Riskesdas 2018. Laporan Nasional Riskesdas 2018, 53(9), 154-65.

Kunitomo et al. (2016). Association between knowledge about comprehensive food education and increase in dental caries in Japanese University Students: A prospective cohort study. Nutrients, 8(3), 1-9. doi: 10.3390/nu8030114.

Lendrawati et al. (2019). Risk factors of dental caries: consumption of sugary snacks among Indonesian adolescents. Pesquisa Brasileira Em Odontopediatria e Clinica Integrada, 19(1), 1-8. doi: 10.4034/PBOCI.2019.191.42.

Sufriani, Aflah Ruhul. (2018). Gambaran menggosok gigi dan kebiasaan mengkonsumsi makanan kariogenik pada anak usia sekolah di SDN 54 Tahija Banda Aceh. Journal Of Syiah Kuala Dentistry Society, 1(3),37-43. 
Taadi, and Almujadi. (2017). Hubungan pengetahuan kesehatan gigi dan mulut terhadap jumlah karies anak kelas III - V di SD Muhammadiyah Sangonan II Godean Yogyakarta. Jurnal Kesehatan Gigi, 04(1), 1-7.

Wala, Hansen Ch. (2014). Gambaran status karies gigi anak usia 11-12 tahun pada keluarga pemegang jamkesmas di Kelurahan Tumatangtang I Kecamatan Tomohon Selatan. E-GIGI, 2(1). doi: 10.35790/eg.2.1.2014.4013. 